\title{
Efficacy of constitutional support to enhance access to essential medicines as a human right to health in the Eastern Mediterranean Region
}

\author{
L.M. Elsayed ${ }^{1}$
}

$$
\begin{aligned}
& \text { كفاءة الدعم الدستوري لتعزيز إتاحة الأدوية الأساسية باعتبارها حقاً أساسياً من حقوق الإنسان الصحية، في إقليم شرق المتوسط } \\
& \text { لمياء السيد }
\end{aligned}
$$

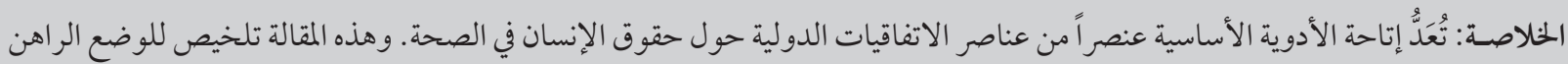

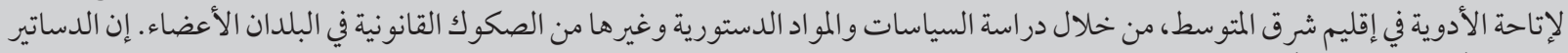

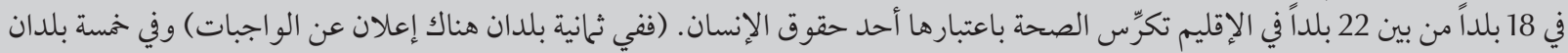

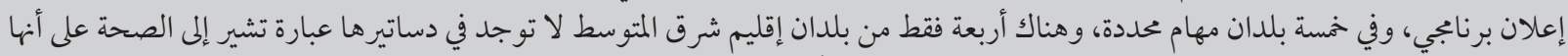

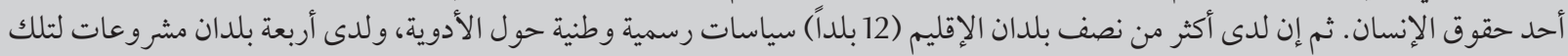

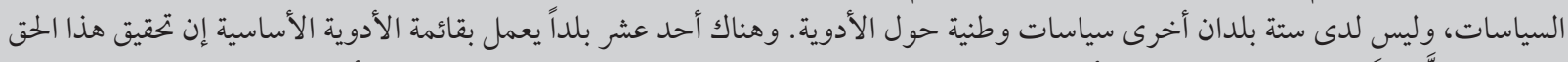

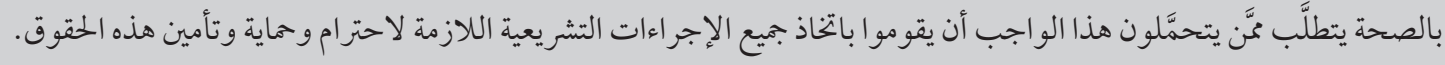

ABSTRACT Access to essential medicines is an element of the international agreements on the human right to health. This review summarizes the current situation concerning access to medicines in the Eastern Mediterranean Region (EMR) by examining the policies, constitutional provisions and other legal instruments of the Member States. The constitutions of 18 out of 22 EMR countries enshrine health as a human right (8 countries have a duty statement, 5 have a programmatic statement and 5 specify entitlement); only 4 EMR countries do not enshrine health as a human right in a clause in their constitution. More than half the countries (i.e. 12) have an official national medicines policy, 4 have a draft policy and 6 have no national medicines policy. A total of 11 countries operate an essential medicines list. Realization of this right to health necessitates that duty bearers take all necessary legislative measures to respect, protect and fulfil this right.

Efficacité de l'appui constitutionnel pour renforcer l'accès aux médicaments essentiels dans le cadre du droit à la santé dans la Région de la Méditerranée orientale

RÉSUMÉ L'accès aux médicaments essentiels est une composante des accords internationaux sur le droit à la santé. L'étude décrit brièvement la situation actuelle de l'accès aux médicaments dans la Région de la Méditerranée orientale en examinant les politiques, les dispositions constitutionnelles et les autres instruments juridiques dont disposent les États Membres. Dix-huit pays de la Région sur vingt-deux ont inscrit la santé en tant que droit de l'homme dans leur Constitution : huit pays y énoncent leurs obligations, cinq pays citent un programme et cinq autres précisent le contenu de ce droit. Dans la Région, seuls quatre pays n'ont pas inclus le droit à la santé dans leur Constitution. Plus de la moitié des pays, c'est-à-dire douze, se sont dotés d'une politique pharmaceutique nationale, quatre pays ont un projet de politique, et six pays n'en ont aucune. Au total, onze pays gèrent une liste de médicaments essentiels. La réalisation du droit à la santé requiert que les responsables prennent toutes les mesures législatives nécessaires pour respecter, protéger et assurer ce droit. 


\section{Introduction}

Medicines can be life-saving, but only if they are available and affordable to people. Globally, one-third of the population lacks reliable access to essential medicines [1]. Those who manage to get medicines are not guaranteed the safety, quality or efficacy of the drugs, the sustainability of supplies or that they will be able to the medicines safely and rationally. As the World Health Organization (WHO) reported: "Around 10 million lives can be saved annually by improving access to essential medicines and vaccines -4 million of them are found in Africa and South-East Asia alone due to unaffordable prices of medicines" [2]. This review summarizes the current situation concerning access to essential medicines in the countries of Eastern Mediterranean Region (EMR) by examining the policies, constitutional provisions and other legal instruments of the Member States.

\section{Human right to health}

\section{History of human right to health in the EMR}

The earliest expression of the concept of human rights in the EMR is found on the Cyrus Cylinder, written in 539 BC during the reign of Cyrus the Great of the Persian Empire (now the Islamic Republic of Iran). Its replica is kept at the United Nations (UN) Headquarters in New York, United States of America (USA), and was translated later into all 6 official UN languages. The cylinder expresses respect for human dignity at a time when servitude, slavery and inhumane treatment were prevailing. Cyrus pronounced the edict to protect the populace of Babylon and other cities, as follows: "I concerned myself with the needs of the Babylonians and their sanctuaries to promote their well-being ... I freed the citizens of Babylon from the yoke of servitude" [3].

The EMR is the birthplace of all 3 monotheistic religions (Islam,
Christianity and Judaism). However, as Islam is the predominant religion in the region, understanding the Islamic concept on human rights in general and on health in particular is important. The Constitution of Medina of 622 $\mathrm{AD}$, which was drafted by the prophet Muhammad 䌆, represents a formal agreement and a social contract that established mutual respect among all the significant tribes and families of Yathrib (later known as Medina), including Muslims, Jews and others. In article 11 of the 47 articles of the Constitution, as documented by Mutalib, respect for human dignity among all tribes without discrimination is evident [4]: "Believers do not forsake a debtor among them, but give him help according to what is fair..."

Al Khayat, Senior Policy Adviser at the WHO Regional Office for the Eastern Mediterranean (EMRO), also suggested how recognition of a human right to health could be derived from Islamic thought [5]: "Islamic teachings require us to feed the body when it is hungry, rest it when it is tired, clean it when it gets dirty, protect it against harm, take precautions against subjecting it to illness, provide it with the necessary treatment when it suffers from disease, and not to overburden it in any way." He further observes that divine law protects 5 essential needs - faith, life, progeny, property and mind. Three of these-life, progeny and mind — cannot be upheld without protection and conservation of health.

In Islam, the right to health imposes a responsibility on individuals, society and the state. This proposition has been affirmed in the preamble of the Universal Islamic Declaration of Human Rights [6]: "Human rights decreed by the Divine Law aim at conferring dignity and honour on mankind and are designed to eliminate oppression and injustice ... these rights can neither be curtailed, abrogated nor disregarded by authorities, assemblies or other institutions, nor can they be surrendered or alienated
In addition, article 1 of the same Declaration enshrines the concept of the sanctity of a person's body even after death: "a) Human life is sacred and inviolable and every effort shall be made to protect it; b) After death, the sanctity of a person's body shall be inviolable...a deceased person's body should be handled with due solemnity" [6].

\section{WHO perspective on access to essential medicines as a right to health}

According to WHO, essential medicines are defined as "those that satisfy the priority health care needs of the population" [7]. The classification of a drug as "essential" is a national responsibility and means that it should be available within the framework of a functioning health system, with assured quality and at an affordable price.

In the UN International Covenant on Economic, Social and Cultural Rights (ICESCR) of 1966, article 12 recognizes "the right of everyone to the enjoyment of the highest attainable standard of physical and mental health" [8]. The Committee on Economic, Social and Cultural Rights' (CESCR) general comment no. 14 on article 12 serves as a key legal reference with regard to access to medicines as a right to health [9], even though it is not legally binding (it is classified as an authoritative guidance emanating from an international agreement). It defines 4 elements - availability, accessibility, acceptability and quality - that should be inherent in any human rights based national health strategy:

- "Availability: of health care facilities, goods (for example essential medicines) and services;

- Accessibility: to physical and economic affordability, information on health facilities, goods and services without discrimination;

- Acceptability: must be respectful of medical ethics and culturally appropriate; 
- Quality: should be scientifically and medically authenticated and of good quality."

Likewise, WHO's framework on access to medicines [10], drafted from a human rights perspective, depends mainly on 4 components in compliance with the above 4 criteria identified by CESCR in general comment no. 14 and the UN millennium development goals (MDG) [11] no. 4 and 8 [12]. WHO also has a medicines strategy, structured from a human rights based approach, through which monitoring and evaluation of implementation of the WHO medicines strategy can be assessed and technical and financial support can be provided (Figure 1) [12].

\section{National constitutions of EMR countries}

\section{Analysis of EMR countries' national constitutions}

Constitution, as defined by Black's law dictionary, is "the fundamental and organic law of a state that defines the scope of governmental sovereign powers, and guarantees individual civil rights and liberties". All constitutions of the EMR countries were adopted after the Second World War, except Lebanon's which was adopted in 1926 and later modified in 1989. According to Black's law dictionary, there are 3 types of constitutions-flexible, rigid and unwritten. The 22 EMR countries all have the rigid type of constitution [13]. This means that any amendment to the provisions of the constitution cannot be enacted except after obtaining the consent of the majority of the members of parliament, bicameral or people's assembly (the definition of a majority percentage differs according to each country's own laws). The EMR countries also have diversity of political regimes, from hereditary monarchies to parliamentary or presidential democratic republics.

There are also differences between EMR countries in their municipal legal systems and how they apply civil law and common law. Due to long periods of colonization, most of the legal systems of Islamic EMR countries apply a civil law system but with "varying degrees of strength" [14]. Most of them apply the principles of Islamic sharia law in their jurisdictions, which comprise a mixture of the French civil code, such as in Djibouti, Egypt, Jordan, Libya, Morocco, Syrian Arab Republic and Tunisia. On the other hand, some countries adopt common law jurisdiction along with other laws, such as in Bahrain, Oman, Pakistan, Somalia (in addition to Somali customary law), Sudan, South Sudan and Yemen. As for Saudi Arabia and Islamic Republic of Iran, Islamic sharia and other secular codes are the main source of their legal systems.

There are 18 out of the 22 Eastern Mediterranean constitutions (82\%) that enshrine health as a human right (Figure 2). Analysing provisions for health and health care in different constitutions around the world Kinney-Clark stated that "the national commitment to health and health care does not necessarily entail it to be included in its national constitution" [15].
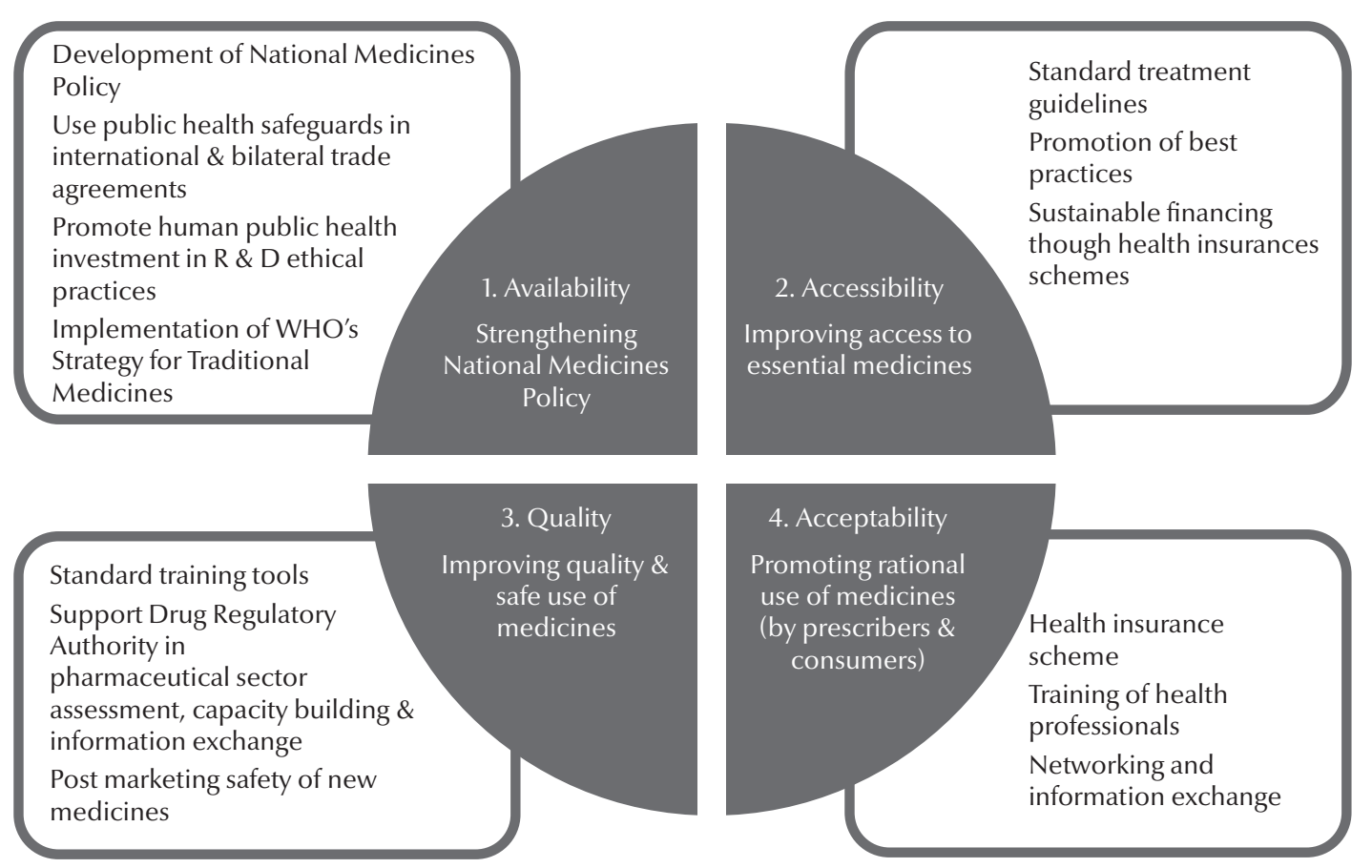

Figure 1 Summary of objectives of the World Health Organization medicines strategy 2004-07 


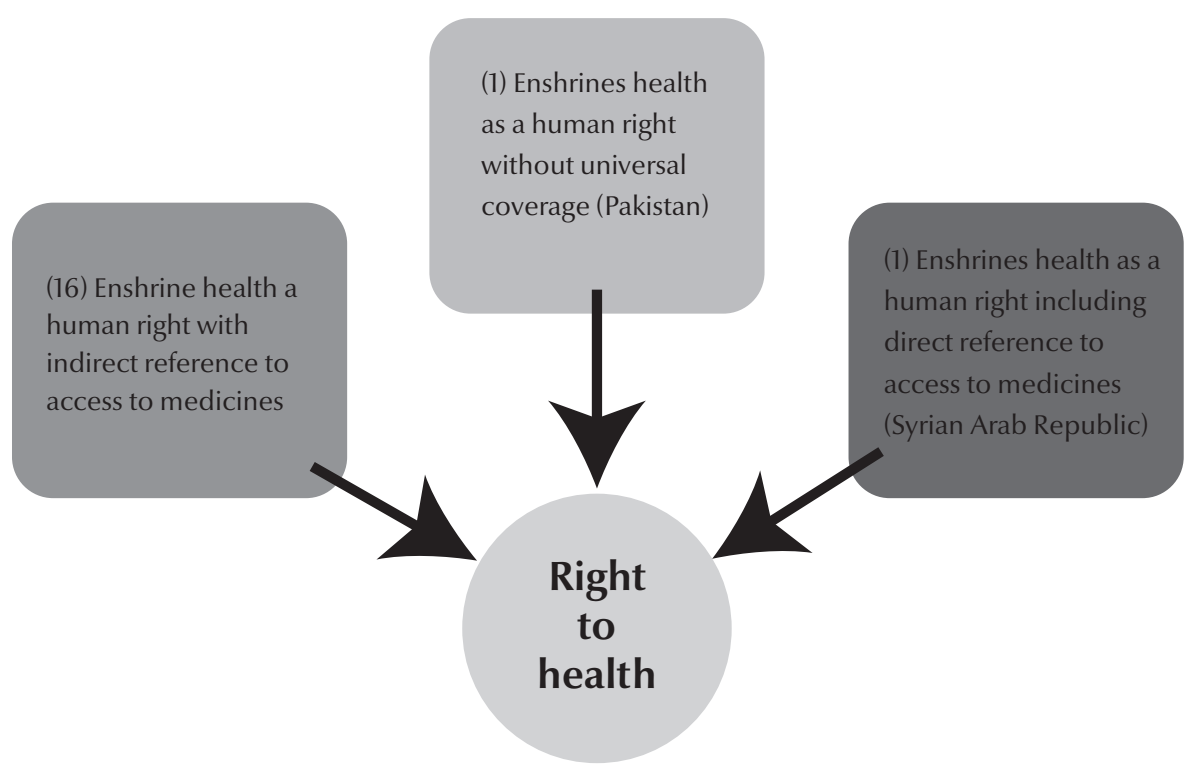

Figure 2 Eastern Mediterranean Region countries with constitutions enshrining health as a human right

Kinney-Clark's typology identified 5 types of constitutional provisions that addressed health and health care in national constitutions as follows:

- A statement of aspiration, stating a goal in relation to the health of its citizens.

- A statement of entitlement, stating a right to health or health care or public health services.

- A statement of duty, imposing a duty to provide health care or public health services.

- A programmatic statement, specifying approaches for the financing delivery or regulation of health care and public health services.

- A referential statement, incorporating by specific reference any international or regional human rights treaties recognizing a human right to health or health care."

The typology ranks the statements of duty and entitlement as reflecting a higher level of national constitutional commitment to health and health care than the other types.

A classification of EMR countries according to the provisions in their constitutional clauses is difficult due to the fact that each constitution has been formulated in the framework of a unique historical background. An analysis of the 18 countries that enshrine health as a human right shows that 8 countries (36\%) have a duty statement, 5 (23\%) have a programmatic statement and 5 (23\%) specify entitlement (Figure 3). The countries that adopt the programmatic type of statement use words such as "ensure", "care", "take care", "encourage" or "protect", which impose fewer obligations on the government. The countries that have entitlement and duty types of statements use more binding phrases such as "the state is obliged", "takes necessary measures", "it is the duty", "shall guarantee by law or "has the right to health by law". Some countries enshrine health in their national constitutions in addition to national legislation; for example, Libya enforces the right to health in its National Health Regulatory Act (no. 106 of $1972 \mathrm{~F}$ and its explanatory notes). Furthermore, Oman enshrines health (including access to medicines) as a human right in a royal decree (no. 10 issued in 1973, revised by no. 41/96 in 1996).

Only 4 EMR countries (18\%) do not enshrine health as a human right in a clause in their constitution (Djibouti, Jordan, Lebanon and Morocco). On examining the health situation of these

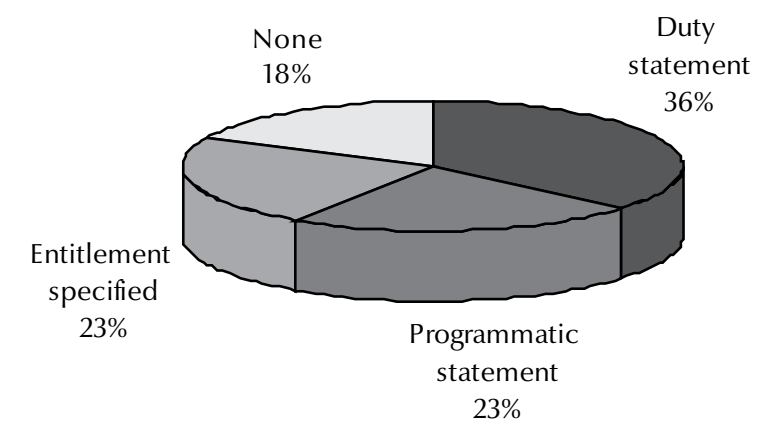

Figure 3 Eastern Mediterranean Region countries with constitutional provisions concerning health as a human right 
countries it is clear that despite the absence of specific mention of health as a human right, the level of commitment of these countries tends to be equal to and often more than other countries which in theory apply this mandate. This is evident in the case of Jordan, in which WHO health indicators based on country data [16] show that in 2007 the percentage of the government budget for the Ministry of Health was 5.6\%. For Lebanon it was 3.0\% and for Morocco $5.4 \%$. In addition, the percentage of the population with access to improved sanitation was $85 \%$ in Djibouti in 2003, $57 \%$ in Jordan in $2005,81 \%$ in Morocco in 2007 (although it should be noted that these data do not necessarily indicate the quality of the health care services).

Djibouti proclaims "the right to health for all" (article 2 under law no. 48/AN/99 on the Orientation of Health Policy of 1999). The same law (articles 103 and 106) states that "the financial availability and accessibility of medication shall constitute the main priority of the national policy on public health...even for the most disadvantaged users". Jordan has had a national medicines policy since 1998, which was revised in 2002. National social health insurance coverage forms $68 \%$ of the total population insured, leaving $32 \%$ uninsured. Some of the population has multiple forms of insurance coverage [17]. In Lebanon, access to medicines for all citizens at their request has been safeguarded since 2009, especially those drugs formulated to treat cancer, kidney diseases, mental illness and chronic diseases (decree no. 10558). Finally, in Morocco, the economic situation and the high cost of drugs means that barriers to access to drugs are high for most of the population and only $16.4 \%$ are covered by health insurance.

There are some useful examples of constitutional clauses that impose an obligation on the state with regard to the health of citizens and include practical steps for fulfilling the right to health by rule of law. The Islamic Republic of Iran's constitution states that: "Health services, and medical care and treatment, provided through insurance or other means, is accepted as a universal right. The government must provide the foregoing services and financial support for every individual" [18]. This is also evident in the Islamic Republic of Iran's national drug policy, where "the National Drug Distribution Charter has been established and announced on the basis of this principle." There is also the constitution of Libya, which states that: "Health care is a right guaranteed by the state through the creation of hospitals and health establishments in accordance with the law" [19]. The Syrian Arab Republic is the only country in the region that states explicitly in its constitution that "the state protects the citizens' health and provides them with the means of protection, treatment, and medication" (chapter I, part IV, article 46, paragraph 2) [20]. This can be interpreted in the light of CESCR's general comment no. 14 on the normative content of article 12, which defines availability [9]: "functioning public health-care facilities, goods, services, and programmes ... will include the underlying determinants of health, such as ... essential drugs, as defined by the WHO Action Programme on Essential Drugs" [21]. Therefore, constitutions including reference to medical treatment, care and services can be considered as en shrining health, including access to medicines, as a human right.

On analysing the constitutions of the EMR countries, it is noted that $\mathrm{Pa}$ kistan is the only country that restricts health services to government employees. The other countries that enshrine health as a human right mention their duty to provide health for all citizens without restrictions [22]. On the other hand Pakistan has a modern legislation (the Drugs Act 1976) and a national list of essential drugs tailored to the health needs of the country. Moreover, it has promoted and encouraged local production of quality-assured medicines until they attain $80 \%$ coverage of the medicines market.

\section{Participation of EMR countries in basic human rights instruments}

Along with the majority of states in the world, the EMR countries follow a dualist system (rather than a monist system, according to which international law becomes automatically applicable and transformed in the domestic law) [23]. Almost all the EMR countries have signed and ratified the binding international treaties on human rightsthe ICESCR and the International Covenant on Civil and Political Rights (ICCPR). The exceptions are 4 of the GCC countries (Oman, Qatar, Saudi Arabia and United Arab Emirates). Ratification of the Convention on the Elimination of All Forms of Discrimination against Women (CEDAW) was also achieved by the great majority of countries, and only Somalia, Sudan and Islamic Republic of Iran refraining from participation. All the EMR countries, except Somalia, have ratified the Convention on the Rights of the Child.

International binding instruments impose obligations on countries besides signature and ratification; they are a tool by which countries can be held accountable through submitting a regular report to "the monitoring committee set up under that treaty on how the rights are being implemented" [24]. Moreover, complaints against countries' human rights' violations can be sent to treaty bodies from nongovernmental organizations, UN agencies, intergovernmental organizations, academic institutions and the media. As a result, sanctions can be imposed on those countries, such as economic sanctions including import/export embargoes, bans on or reduction of financial aid, trade restrictions and political sanctions. 


\section{Policies of EMR countries and barriers to access to medicines}

\section{Analysis of EMR countries' national medicines policies}

WHO has stated that: "A national drug policy expresses and prioritizes the medium-to long-term goals set by the government for the pharmaceutical sector, and identifies the main strategies for attaining them" [25].

Information gathered through WHO country offices in EMR and ministry of health official websites shows that a total of 12 of the 22 countries have an official national medicines policies (NMP), 4 have a draft NMP and 6 have no NMP (Figure 4). Moreover, 11 countries operate an essential medicines list. Most of the countries that have an NMP share the same main objective, which is to provide and promote equitable access to quality assured essential medicines to all people, without discrimination. However, each country differs in setting its own priorities, areas of focus and framework for implementation.

\section{WHO/EMRO classification of countries' health systems}

WHO/EMRO has classified the countries into 4 groups according to the level of development of their health systems [7]. The study adopted this classification in identifying main challenges and best practices as observed from the NMPs and legislations that can be shared among groups having the same level of health system development.

\section{Group A}

Group A includes countries in a constant state of emergency (Afghanistan, Iraq, Lebanon, Palestine, Sudan, South Sudan and Somalia), in which the availability-accessibility-acceptabilityquality criteria are almost unattainable.

Major challenges and barriers to access to medicines. A constant state of emergency results in a dysfunctional health system and the absence of a unified law on medicines to integrate the scattered laws and regulations. There is a lack of: sustainable supply of quality assured medicines; financial resources; qualified personnel (in all fields); health insurance schemes (in some of the countries); respect of patients' rights; and access to medicines. In remote areas such as South Sudan medicines expire even before distribution due to the unavailability of transport [26].

Best practices. Establishing medicines information centres to provide consumers and prescribers with adequate information on the safe use of regular, alternative and traditional medicines (such as in Afghanistan).

\section{Group B}

Group B includes countries with relative stability, low to medium income and comparatively low population growth rates (Djibouti, Jordan, Libya, Morocco, Syrian Arab Republic, Tunisia and Yemen). The challenges differ

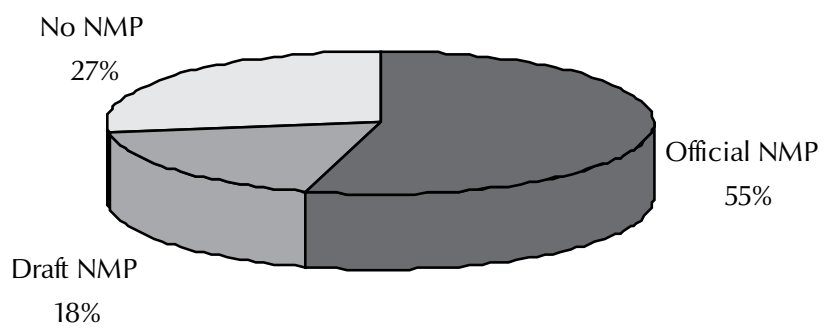

Figure 4 Eastern Mediterranean Region countries with a national medicines policy (NMP)

from those of group A as their level of health systems is more advanced.

Major challenges and barriers to access to medicines. These include: high outof-pocket expenditure on medicines for the population; a low proportion of budget allocation to health from countries' gross domestic product; and inadequate drug procurement systems from the private to the public sector. There is also a lack of technical capability and human resources, which impedes the implementation of policies.

Best practices. Establishment of a joint drug procurement system within the country by the private and public sectors (such as in Jordan); and enforcement of the role of civil society in promoting access to medicines and promotion of local production and selfsufficiency of medicines (for example in the Syrian Arab Republic) [27].

\section{Group C}

Group C includes countries with relatively sizeable populations and low to medium income (Egypt, Islamic Republic of Iran and Pakistan). They have well established local production of pharmaceuticals.

Major challenges and barriers to access to medicines. These include: the escalating expenditure on pharmaceuticals; limited financial resources; geographical distribution of pharmacies; and how to "ensure patients' round-the-clock" access to medicines [28]. Egypt's law no. 79 of 1975 affirms that the state is obliged to cover the costs of all types of medical treatment and dispensing of medicines to all citizens, as stipulated in article 47 of the same law and other acts and laws. However, due to overpopulation and limited resources, the country has not yet included all citizens under health or social insurance coverage [29].

Best practices. In Egypt, priority has been given to research and development in order to comply with provisions stipulated under the Trade-Related Aspects of Intellectual Property (TRIPS) 
agreement. Sometimes, however, health care teams are not fully aware of how to implement the medicines policy, and training sessions or awareness programmes are needed.

In the Islamic Republic of Iran, the local pharmaceutical industry has sought to increase its market share by manufacturing medicines whose importation imposes the greatest financial burden on the country's health system. Due to overpopulation, the Egyptian health authorities encourage responsible self-medication to alleviate some of the burden on health care facilities and practitioners. In Pakistan, a law to regulate the use of traditional medicines will be promulgated and the bulk purchase of medicines within the country will be promoted [30].

\section{Group D}

Group D includes Gulf Cooperation Council (GCC) countries (Bahrain, Kuwait, Oman, Qatar, Saudi Arabia and United Arab Emirates), which have political stability, high incomes and standard of living and efficient functioning health systems. This has resulted in almost $100 \%$ health coverage, including access to medicines, for their citizens.

Major challenges and barriers to access to medicines. Inadequate forecasting of medicines needs and increases in the number of expatriate workers are among the major challenges that face the GCC countries.

Best practices. Bulk procurement of medicines and vaccines have helped the countries to offer quality medicines with remarkable cost-effectiveness. The programme has seen substantial growth in the past 2 decades and is considered to have contributed to accelerated achievements in immunization programmes in the region, including the introduction of new vaccines [31]. Moreover, the use of effective online pharmacy management systems has had a great impact on promoting access to medicines for the population. As a result, most of the GCC countries provide full coverage and free access to medicines to their citizens and partial coverage to expatriates [32].

\section{Conclusions}

The situation in the EMR is alarming with regards to access to medicines as a human right to health. Most of the states' legal provisions need to be revised and reformed in order to comply with the international legal instruments that the countries have willingly and voluntarily ratified. In practice, many human rights are difficult to enforce legally due to "the absence of a consensus on the application of certain rights, the lack of relevant national legislation or the lack of an enforcement mechanism" [33]. It is not only the problem of scarcity of funds that impedes access to essential medicines, as sometimes such funds are available, but that drugs are wasted due to the lack of qualified personnel and adequate planning.

The question of whether states are unable, or unwilling, to realize and enforce health as a human right cannot be determined except after conducting in-depth case studies for each country individually, in which all aspects related to this issue are included and examined.

Finally, the right to health needs to be progressively realized and claimed by the holders of that right, respected by other stakeholders and duty bearers and promoted by the community at large and at all levels.

\section{Acknowledgements}

I am indebted in the development of this article, which is based on my LLM thesis research, to Dr Eleanor D. Kinney, Hall Render Professor of Law, Co-Director, William S. and Christine S. Hall, Center for Law and Health, Indianapolis, USA and Dr Zafar Mirza, Coordinator, Public Health Innovation \& Intellectual Property, Innovation, Information, Evidence and Research Cluster, World Health Organization, Geneva, Switzerland.

\section{References}

1. Measuring medicine prices, availability, affordability and price components, 2nd ed. Geneva, World Health Organization/ Health Action International, 2008.

2. Eastern Mediterranean Region medicines situation. World Health Organization, Regional Office for the Eastern Mediterranean [website] (http://www.emro.who.int/emp/ medicines_regional_situation.htm accessed 15 November 2011).

3. Statement by Secretary-General $U$ Thant at presentation of gift from Iran to United Nations, 14 October. New York, United Nations, Office of Public Information, 1971) (Press Release SG/ SM/1553/HQ263).

4. Mutalib H. Islam in Malaysia: from revivalism to Islamic state? Appendix I. Singapore, Singapore University Press Singapore, 1993.
5. Al Khayat $\mathrm{H}$. The right to health in Islamic Society. Human rights in support of the right to health. Report on an Intercountry Meeting on Health and Human Rights. Cairo, World Health Organization, Regional Office for the Eastern Mediterranean, 12-14 July, 2005.

6. Universal Islamic Declaration of Human Rights: 19 September 1981. London, Islamic Council, 1981 (http://rsq.oxfordjournals.org/content/27/2/70.full, accessed 22 November 2011).

7. Essential medicines. World Health Organization [online factsheet] (http://www.who.int/topics/essential_medicines/ en/, accessed 21 November 2011).

8. International Covenant on Economic, Social and Cultural Rights. Office of the United Nations High Commissioner for Human Rights [website] (http://www2.ohchr.org/english/law/cescr. $\mathrm{htm}$, accessed 22 November 2011). 
9. The right to the highest attainable standard of health: 11/08/2000 E/C.12/2000/4, CESCR General Comment 14. Twenty-second session Geneva, 25 April-12 May 2000 Agenda item 3. United Nations Committee on Economic, Social and Cultural Rights [website] (http://www.unhchr.ch/tbs/doc.nsf/(symbol)/ E.C.12.2000.4.En, accessed 22 November 2011).

10. Equitable access to essential medicines: a framework for collective action. Geneva, World Health Organization, 2004 (Policy Perspectives on Medicines No. 8).

11. MDG summit 2010. World Bank Group [online facsheet] (http://data.worldbank.org/news/mdg_summit_2010, accessed 22 November 2011).

12. Medicines policy. World Health Organization [website] http:// www.who.int/medicines/areas/policy/en/, accessed 22 November 2011).

13. Black's law dictionary, 8th ed. Eagan, Minnesota, Westlaw, 2004.

14. The World factbook. Central Intelligence Agency [online database] (https://www.cia.gov/library/publications/the-worldfactbook/index.html, accessed 22 November 2011).

15. Kinney ED, Clark BA. Provisions for health and health care in the constitutions of the countries of the world. Cornell International Law Journal, 2004, 37:285-355.

16. Demographic, social and health indicators for countries of the Eastern Mediterranean. Cairo, World Health Organization, Regional Office for the Eastern Mediterranean, 2008 (WHO-EM/ HST/206/E)

17. Ministry of Health, Hashemite Kingdom of Jordan [website] (http://www.moh.gov.jo/MOH/En/about.php, accessed 22 November 2011).

18. Constitution of the Islamic Republic of Iran, 1979, Chapter III, Article 29.

19. Constitution of Libya, 1969, Chapter 1, Article 15.

20. Constitution of the Syrian Arab Republic, 1973, Chapter I, Part IV, Article 46, Paragraph 2.
21. WHO model list of essential medicines, 13th list. Geneva, World Health Organization, 1999.

22. Constitution of Pakistan, 1973, Chapter II, Article 38(c).

23. Murphy S. Principles of international law (Concise Hornbooks). St Paul, Minnesota, Thomson/West, 2006:14-18.

24. Office of the High Commissioner for Human Rights [website] (http://www2.ohchr.org, accessed 22 November 2011).

25. How to develop and implement a national drug policy, 2nd ed. Geneva, World Health Organization, 2001.

26. Alumni workshop on health and human rights. Dar Es Salam, Tanzania, United Nations Development Programme Office, 2009.

27. National medicines policy. Damascus, Syrian Arab Republic, Ministry of Health, 2007.

28. National medicines policy. Tehran, Islamic Republic of Iran, Ministry of Health, 2004.

29. National medicines policy. Cairo, Egypt, Ministry of Health and Population, 2004-05.

30. National drug policy. Ministry of Health, Pakistan [website] (http://www.dcomoh.gov.pk/publications/ndp.php, accessed 22 November 2011)

31. De Roeck D et al. Regional group purchasing of vaccines: review of the Pan American Health Organization EPI revolving fund and the Gulf Cooperation Council group purchasing programme. International Journal of Health Planning and Management, 2006, 21:23-43.

32. National medicines policy. Muscat, Oman, Ministry of Health, 2000 (http://www.moh.gov.om/pharma/ndpeng.pdf, accessed 22 November 2011).

33. Hegarty J, Gielen F, Hirata Barros AC. Implementation of international accounting and auditing standards. Lessons learned from the World Bank's auditing and accounting ROSC program. Washington DC, World Bank, 2004 (http://worldbank.org/ifa/ LessonsLearned_ROSC_AA.pdf, accessed 21 November 2011). 